\title{
Occurrence, morphology and ultrastructure of the Dufour gland in Melipona bicolor Lepeletier (Hymenoptera, Meliponini)
}

\author{
Fábio Camargo Abdalla ${ }^{1} \&$ Carminda da Cruz-Landim ${ }^{1}$
}

${ }^{1}$ Departamento de Biologia, Instituto de Biociências, Universidade Estadual Paulista (UNESP). Avenida 24 A 1515 , 13506-900
Rio Claro-SP, Brazil.

\begin{abstract}
Resumo. Ocorrência, morfologia e ultra-estrutura da glândula de Dufour em Melipona bicolor Lepeletier (Hymenoptera, Meliponini). A ocorrência, morfologia e ultra-estrutura da glândula de Dufour em Melipona bicolor Lepeletier, 1836 são apresentados. A glândula de Dufour não está presente nas operárias. Nas rainhas virgens, as células glandulares mostram características de baixa atividade, as quais são descritas no texto. Nas rainhas fisogástricas, o epitélio glandular é mais alto e as células mais ativas do que nas rainhas virgens, mostrando numerosas invaginações da membrana plasmática basal impregnadas por material eletrondenso, além do aumento da frequiência de invaginações apicais e acúmulo de substâncias no espaço subcuticular, as quais serão posteriormente liberadas ao lúmen da glândula. Portanto, os dados mostram que a glândula de Dufour é mais desenvolvida nas rainhas fisogástricas do que nas virgens, indicando um possível envolvimento da glândula de Dufour na reprodução desta espécie.
\end{abstract}

Palavras-Chave. Glândula de Dufour; Melipona bicolor; meliponíneo; morfologia; ultra-estrutura.

Aвstract. The occurrence, morphology and ultrastructure of the Dufour gland in Melipona bicolor Lepeletier, 1836 are presented. The Dufour gland is not present in workers. In virgin queens the gland cells show characteristics of low activity, which are described in the text. In physogastric queens the gland epithelium is higher and the cells more active than in virgin queens, showing numerous basal plasmic membrane invaginations impregnated by an electrondense material, increased apical invaginations and accumulation of substances that will be released to the gland lumen in the subcuticular space. Therefore, the data show that the Dufour gland is more developed in physogastric than in virgin queens, indicating a possible involvement of the Dufour gland in the reproduction of this species.

KEYwORDS. Dufour gland; Melipona bicolor; meliponine; morphology; ultrastructure.

The Dufour gland, known as one of the sting glands in bees, is homologous to the accessory gland of the female reproductive apparatus. In the bees, it is located close to the base of the sting, ventrally to the poison gland, and opens into the vagina (BILLEN 1987).

The Dufour gland is generally described as a tube, or sacklike organ, whose walls are constituted by a single layered epithelium, and the luminal surface lined by a thin cuticle. Externally to the epithelium, an irregular layer of muscle fibers and tracheoles covers the gland. In Aculeata eusocial bees, it is more developed in queens than in workers (ABDALLA 2002; AbDalla \& CRuZ-Landim 2001c).

In stingless bees, the Dufour gland is always present in all queens, but it is not a constant in workers (Lello 1968). Although almost nothing is known about its morphology and function, there is only one report about the chemical composition of the secretion in workers of Nanotrigona testaceicornis (CRUZ-LÓPEZ et al. 2000).

The present investigation focused on the occurrence, morphology and ultrastructure of the Dufour gland of Melipona bicolor Lepeletier, 1836 (Meliponini), a species that presents facultative polygyny (KERR 1949), in order to establish the relationship between the glandular features and the reproductive characteristics of the species.

\section{MATERIALAND METHODS}

Ten newly emerged, nurse and forager workers were studied, as well as ten virgin and four physogastric queens of M. bicolor. The bees have been captured in polygynic colonies maintained in the meliponary of the Departamento de Biologia (UNESP - Rio Claro, SP, Brazil), in the Laboratory of Bees (USP - São Paulo, SP, Brazil) and in the meliponary of the Universidade Federal de Viçosa (Viçosa, MG, Brazil).

Light Microscopy (LM) - Routine. The posterior half of the workers' abdomens, that supposedly would contain the Dufour gland, were cut off and fixed in $4 \%$ paraformaldehyde for, at least, 2 hours and then embedded in historesin, following the usual procedures. The histological sections were stained with haematoxylin and eosin (HE) and observed through a photomicroscope.

Transmission electron microscopy (TEM) - Routine. The queen's glands were fixed in $2 \%$ glutaraldehyde and $4 \%$ paraformaldehyde in $0.2 \mathrm{M}$ sodium cacodilate buffer at $\mathrm{pH} 7.2$ for, at least, 2 hours. After fixation, the glands were washed twice in $0.2 \mathrm{M}$ sodium cacodilate buffer, post-fixed in $1 \%$ osmium tetroxide in the same buffer and stained with $2 \%$ uranyl acetate in $10 \%$ ethanol during $2 \mathrm{~h}$, being then dehydrated in a series of acetone (30-100\%). The glands were embedded in 
resin Epon Araldite, following the usual procedures. Thin sections were cut with a diamond knife, stained with lead citrate, and examined under electron microscope. Some thick sections were also stained with methylene blue - azur II for LM.

Morphometric and statistical analyses. The heights of the glandular epithelium of ten virgin and four physogastric queens were measured with aid of the software Impact-Graphic Application $^{\mathrm{TM}}$ that allows the measurement and calculation of the epithelium heights directly on the histological sections.

As preliminary statistical analysis, a variance analysis of the sample was done. After that, the data were submitted to the Tukey-test with 5\% level of significance to verify differences among the queen groups studied. The averages and coefficients of variations obtained for each queens group studied were also calculated.

\section{RESULTS AND DISCUSSION}

Occurrence of the Dufour gland in workers. The Dufour gland is not found in M. bicolor adult workers. Although the Dufour gland may be considered as a sting gland in hymenopterans, it is always more developed in queens than in workers of bees, being present in workers of some species of stingless bees (LELLo 1968).

Several functions are attributed to this gland in female bees; most of them related to the reproductive behavior, as for instance nest demarcation (HeFETz 1987). Nevertheless, the function of the Dufour gland in eusocial bees is not well known. In the foraging workers of Apis mellifera Linnaeus, 1758 (Apini) its secretion seems to be used as alarm pheromone (ABDALLA \& CRUZ-Landim 2001a). It is also known that in queen less colonies the laying workers may synthesize some of the compounds present in the Dufour gland secretion of the queens, which are not produced by workers on queen right colonies (KATZAv-GoZANSKY et al. 1997). These data suggest a close relationship between the reproductive status of the bee and the Dufour gland.

In meliponines, the gland is commonly absent in workers and although present in queens, it is apparently less developed than in the aculeated species. This feature led KerR \& Lello (1962) to postulate a relictual character to the gland in this group of bees. Considering the reproductive functions, it was observed that this group of bees shows several patterns of ovary development (ZucCHI et al. 1994), suggesting that the gland would be present in workers of those species that present developed ovaries and functional egg laying activity. However, this reproductive correspondence was not found (ABDALLA 2002). Therefore, in meliponines the presence or absence of the gland is not related to the worker fecundity degree and may reveal just different degrees of involution of the character among them, e.g., this gland in workers would be a relict organ as postulated by KeRR \& LeLLo (1962) .

Dufour gland in queens. In spite of the possibility of the relictual character of the Dufour gland in meliponine workers, and its assumed absence in the Melipona species (PATRício 1995), the queens have functional glands.

The queens' Dufour gland in M. bicolor consists of a sack-like organ, composed of a single layer of epithelial cells, which is lined by a thin cuticle at the luminal surface. The gland lumen is wide (Figs. 1A,B) if compared with that of $A$. mellifera queen glands (ABDALLA \& CRUZ-LANDim 2001b), and irregular due to folds of the glandular epithelium (Figs. 1B,C).

The glandular cells vary from cubic to columnar. The nuclei of the columnar cells are located at the basal portion and in both cells usually with irregular contour, showing, sometimes, more than one nucleolus (Figs. 1B,C).

Muscular fibers outer the epithelium (Fig. 1D) do not involve the gland completely, as they do in A. mellifera, Bombus terrestris Linnaeus, 1758 (Bombini) and other species of bees (Lello 1968; Barrows et al. 1986; AbDalla \& CRUZLANDim 2001b; AbDalla et al. 1999a, b). Tracheoles are found among the epithelial folds and in the intercellular spaces between the gland cells (Fig. 1B).

The cytoplasm presents abundant smooth endoplasmic reticule (SER) and occasionally rough endoplasmic reticule (RER). Mitochondria and polyribosomes are abundant, being also present Golgi complexes and disperse secretion granules in the cytoplasm. The apical and the basal cell portions present invaginations of the plasmic membrane (Figs. 1C, 4A, 6B), which vary in depth according to the glandular cell activity state.

The cellular ultrastructure, abundant SER (Fig. 2C) and secretion with characteristic ground electrondensity (Figs. $1 \mathrm{~A}, \mathrm{~B}, \mathrm{C})$, is compatible with the lipidic nature of the secretion, as observed by gas chromatography and mass spectrometry (unpublished data).

Ultrastructural differences between the Dufour gland of virgin and physogastric queens. The cells of the Dufour gland of virgin queens are low and, generally, present few apical and basal plasmic membrane invaginations (Figs. 1C, D, 2B). The contact among them is sinuous, forming an intricate course, frequently reinforced by septated junctions in the apical portion (Figs. 2A,B,d). This reinforcement may be absent in the basal portion, where the intercellular spaces are open (Figs. 3A, B).

The cytoplasm of the glandular cells shows polymorphic mitochondria, microtubules, SER, polyribosomes and, less frequently, Golgi complexes (Figs. 2C, D). A tubular SER system may form a belt-like surrounding to the cell, being quite visible margining the lateral plasmic membranes (Fig. 2E).

The Dufour gland in the newly emerged queens presents few stored secretion in the lumen, but in older virgin queens this was much more abundant (Figs. 1A,B). The basal plasmic membrane invaginations in virgin queens, when present, form extensive inner canals that branch or take a loop-like form (Figs. 3A,B). The canals' lumen is continuous with the surrounding outer space of the gland and may or not be filled by the basal lamina of the glandular cell, which in these queens is frequently electron-transparent (Fig. 3A,B). In the cytoplasmic, mitochondria and many vesicles of varying sizes 

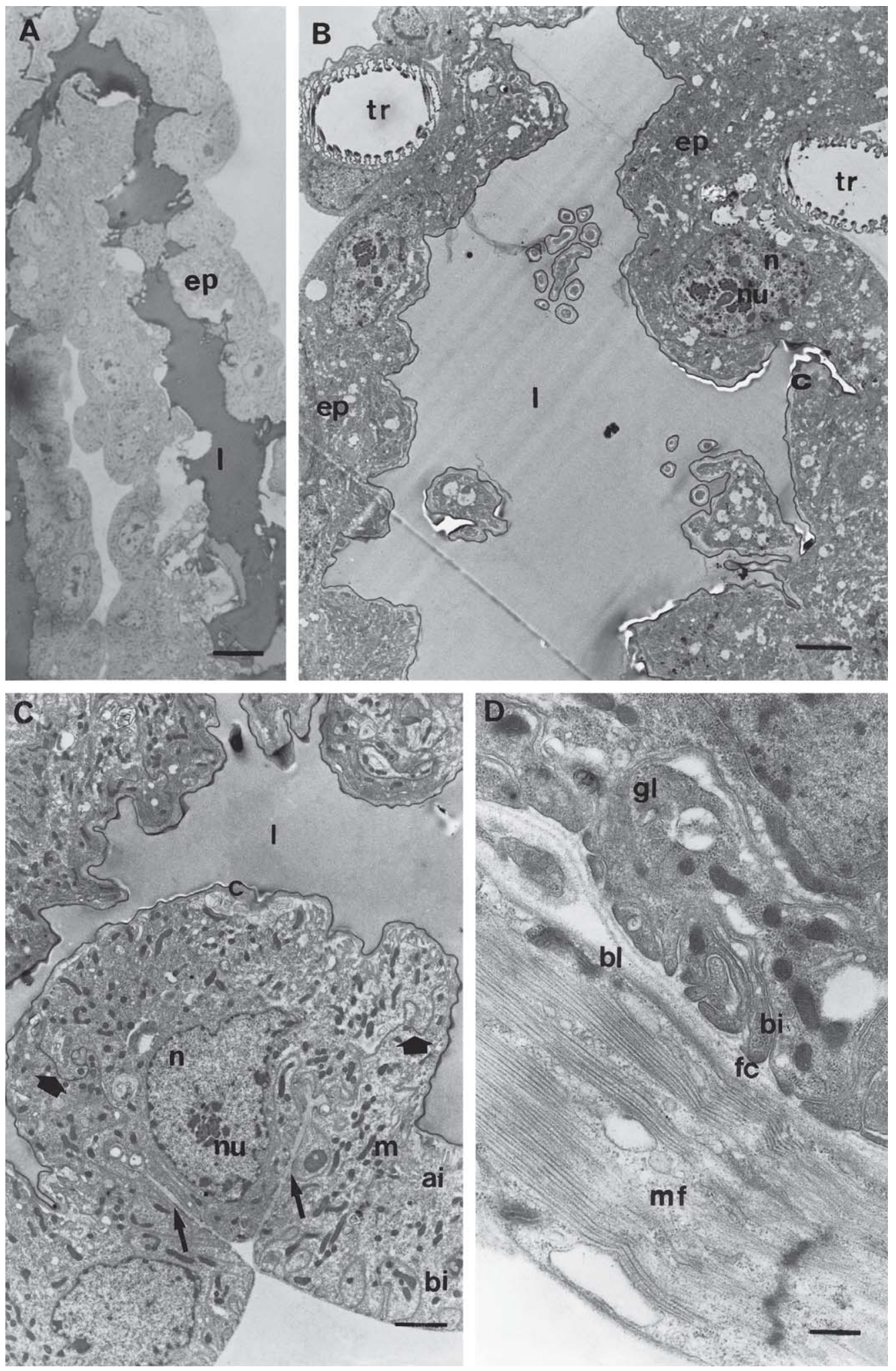

Fig. 1. General aspect of virgin queens' Dufour gland. A) Photomicrograph of the epithelium (ep) and of the gland lumen (1), Methylene Blue Azur II. Bar $=34 \mu \mathrm{m}$. B) Micrograph with Transmission Electron Microscopy (TEM) of the glandular epithelium (ep); c, cuticle; 1, lumen; n, nucleus; nu, nucleoli; tr, tracheoles. Bar $=3 \mu \mathrm{m}$. C) TEM micrograph of a fold (arrows) of the glandular epithelium. In the glandular cell may be observed the sinuous intercellular limits (arrowhead) and many mitochondria (m); ai, apical plasmic membrane invagination; bi, basal plasmic membrane invagination; c, cuticle; 1, lumen; $\mathrm{n}$, nucleus; nu, nucleoli. Bar $=2 \mu \mathrm{m}$. D) TEM of the basal portion of the gland (gl), which is involved by a thick muscular fiber (mf); fc, focal contacts; bi, basal plasmic membrane invagination, bl, basal lamina. Bar $=0.6 \mu \mathrm{m}$. 

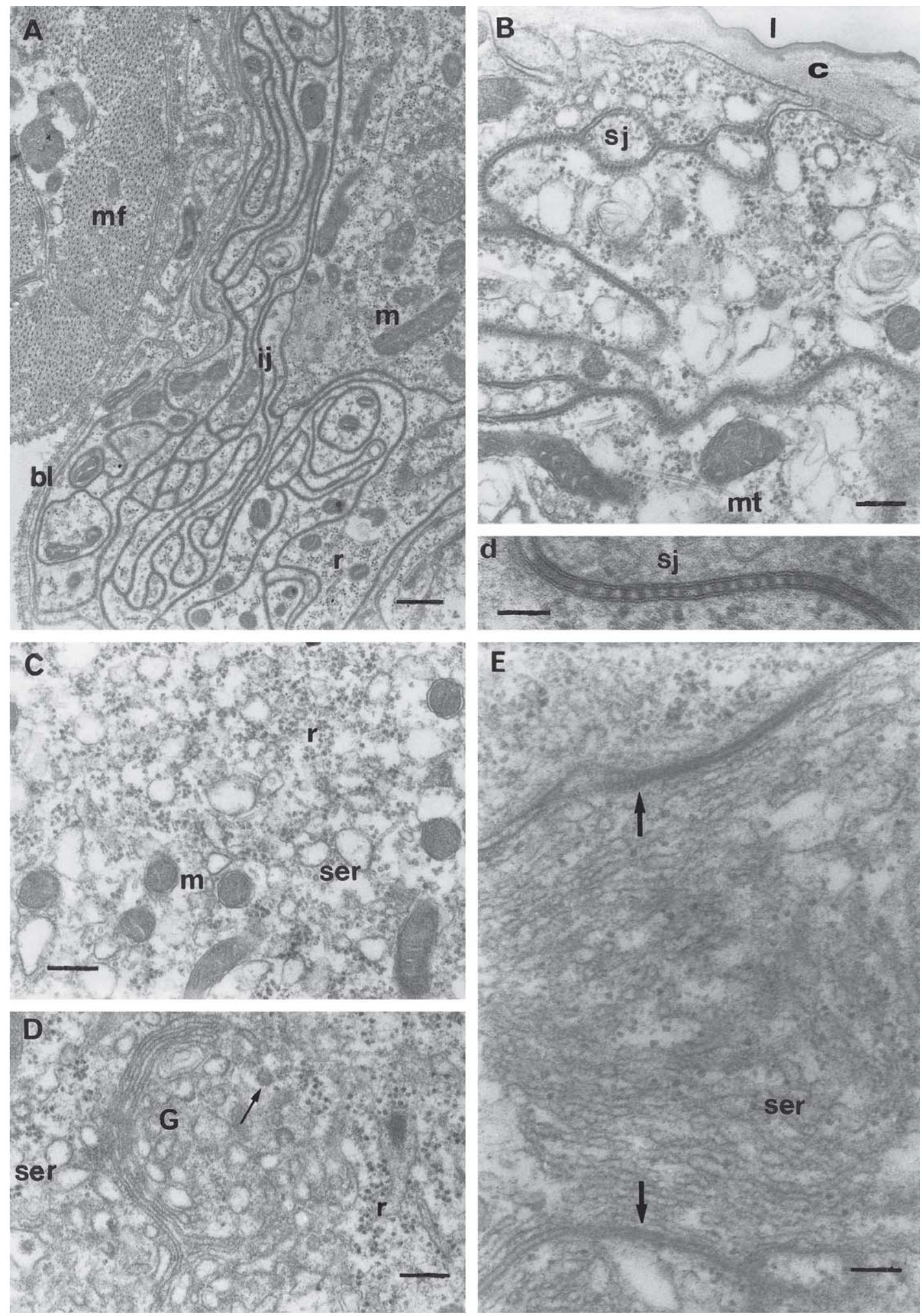

Fig. 2. TEM of virgin queens' Dufour gland. A) Basal portion of the gland, evidencing a sinuous intercellular junction (ij); mf, muscular fiber; bl, basal lamina; $\mathrm{m}=$ mitochondria; $\mathrm{r}$, polyribosomes. $\mathrm{Bar}=0.6 \mu \mathrm{m}$. B) Apical portion of a glandular cell; $\mathrm{c}$, cuticle; $\mathrm{m}$, mitochondria; mt, microtubule; sj, septated junction. Bar $=0.3 \mu \mathrm{m}$. Below, detail (d) of the septated junction (sj) seen in B). Bar $=0.1 \mu \mathrm{m}$. C) Detail of the cytoplasm of a glandular cell; $\mathrm{m}$, mitochondria; ser, smooth endoplasmic reticule; $r$, polyribosomes. Bar $=0.3 \mu \mathrm{m}$. D) Portion of the cytoplasm of a glandular cell where it is observed a active (arrow) Golgi $(\mathrm{G})$, flat smooth endoplasmic reticule (ser) and polyribosomes $(\mathrm{r})$. Bar $=0.2 \mu \mathrm{m}$. E) Smooth endoplasmic reticule (ser) forming a belt-like surrounding the glandular cell (arrows). Bar $=0.2 \mu \mathrm{m}$. 
associated with the plasmic membrane invaginations, are observed (Figs. 3A,B).

The basal and apical plasmic membrane invaginations are attached to the basal lamina or to the cuticle, respectively, by focal contacts, and in the basal portion are sustained by microtubules (Figs. 1D, 3B). These plasmic membrane invaginations have also been described for A. mellifera and B. terrestris gland cells (ABDAlla et al. 1999a, b; ABDAlLa \& Cruz-Landim 2001b).

Externally to the gland, large granules with the same electrondensity of the secretion in the lumen (compare Figs. $1 \mathrm{~B}$ and $3 \mathrm{C}$ ), and numerous small and electron-transparent vesicles are observed associated to the basal lamina (Figs. 3C, D). The small vesicles (Fig. 3D) are very similar to those of the Fig. 3A. Similar structures have been already observed in $B$. terrestris and seem to constitute extracellular material of lipid nature that could be absorbed by the gland (ABDALLA et al. 1999a, b). In A. mellifera, the Dufour gland of queens and workers absorbs, probably from the hemolymph, all the hydrocarbons present in the gland secretion (KATZAVGozANSKY et al. 2000).

In physogastric queens a more intense glandular activity is observed. The apical plasmic membrane invaginations are more numerous and deeper (Fig. 4A), being the cytoplasm replete of mitochondria and SER tubules with electrondense material inside (Fig. 4B). Golgi complexes and RER cisternae are also observed (Figs. 4C, D).

Interestingly, very well developed annulated lamellae are observed close to the nuclear membrane (Fig. 4E). The frequent proximity of these lamellae with the nucleus and the similarity of their annulus with the nuclear pore complexes led to the supposition that this structure has origin from the nuclear envelope and probably constitute a way of increasing the amount of endoplasmic reticulum (FAWCETT 1981).

The intercellular junctions in the glandular cells of the physogastric queens were frequently smooth, united by septated desmosomes in the apical portion and opened in the basal portion. Besides the presence of these junctions, the intercellular space contains electrondense material passed through them and released to the gland subcuticular space (Figs. 5A, B, d, C, D). Material of homogeneous electrondensity is observed in the space formed between the glandular cell basis and the muscular fibers (Fig. 6A). This feature was also observed in queens of A. mellifera and B. terrestris (ABDALLA et al. 1999a, b; ABDALLA \& CRUZ-LANDim 2001b) and may represent material that will be absorbed by the cell, through the plasmic membrane invaginations, branched and loop-like organized and associated with mitochondria, which are observed in the cell basal portion. Vesicles with two or four membrane units and with variable electrondensity are observed in the cytoplasm (Figs. 5D,E), and may be modified mitochondria. These structures seem to be common in this gland in other species of bees and ants (AbDalla \& CRuZLANDIM 2001c; CAETANO 2002).

The differences described between the virgin and physogastric queen Dufour gland permit to affirm that this gland is functional in this species, which is related to the reproductive state of the individual. Therefore, the gland is not just topographically associated to the sting but in fact functionally associated to the reproductive tract of the bees. The observation made by BILLEN (1987) that in bees the secretion of the Dufour gland is delivered in the vagina is in accordance with this function, as well as the homology of the gland to the colleterial gland of other insects.

Origin of the secreted gland material. The morphological features of the gland cells suggest that at least a part of the products in gland lumen is not synthesized in the cells, but absorbed directly from the hemolymph.

Material circulation through intercellular space is common in epithelia, being demonstrated that the septated junctions are permeable to some substances, as the lanthanum (LANE 1981), what would easily signalizes the absorption mechanism of the Dufour gland. However, the lanthanum technique in this gland showed that this substance is barred at the apical portion by these junctions (data not shown). Besides, material from the intercellular space, by routine technique, is clearly shown to pass through the septated junctions going to the subcuticular space (Fig. 5C). Therefore, in this case, the presence of septated junctions in the apical portion may be selective, preventing the free entrance and/or exit of substances present in the lumen of the gland. The basal portion of the intercellular spaces is wider in physogastric queens, which might indicate more intensive use of this path for circulation of substances.

The most evident difference between the glands of virgin and physogastric queens occurs in the basal portion of the glandular cells. While in virgin queens the basal lamina is electron-transparent and the cells possess generally few basal plasmic membrane invaginations, in the physogastric queens it is impregnated by a very electrondense material that also fills the lumen of the canals of the countless plasmic membrane invaginations that form an extensive basal labyrinth in the cell (Figs. 3A, B, 5B, d, 6B).

In this way, the features suggest that the substances of the secretion may come from the hemolymph into the lumen, crossing the plasmic membrane of the invaginations or through the intercellular spaces, entering in the cell. The basal and apical labyrinth formed by the cell invaginations represent an increase of the absorption surface in the basal side and deliver surface in the apical side. The fact that the increasing in both sides of the glandular cell surfaces is great in the physogastric queens reveals a higher function in these individuals. In fact, in the apical portion, a greater number of plasmic membrane invaginations is observed in physogastric queens and the subcuticular space is wider and contain material for discharging in the lumen (Figs. 2B, 4A, 5C, D).

Secretion granules, multivesicular and myelinic bodies (Figs. 5A, 6C, D) are more frequently observed in the glands of physogastric queens, being more frequently located in the basal portion of the cells. The two structures may represent an indicator of cellular wastes from organelles re-absorption, 

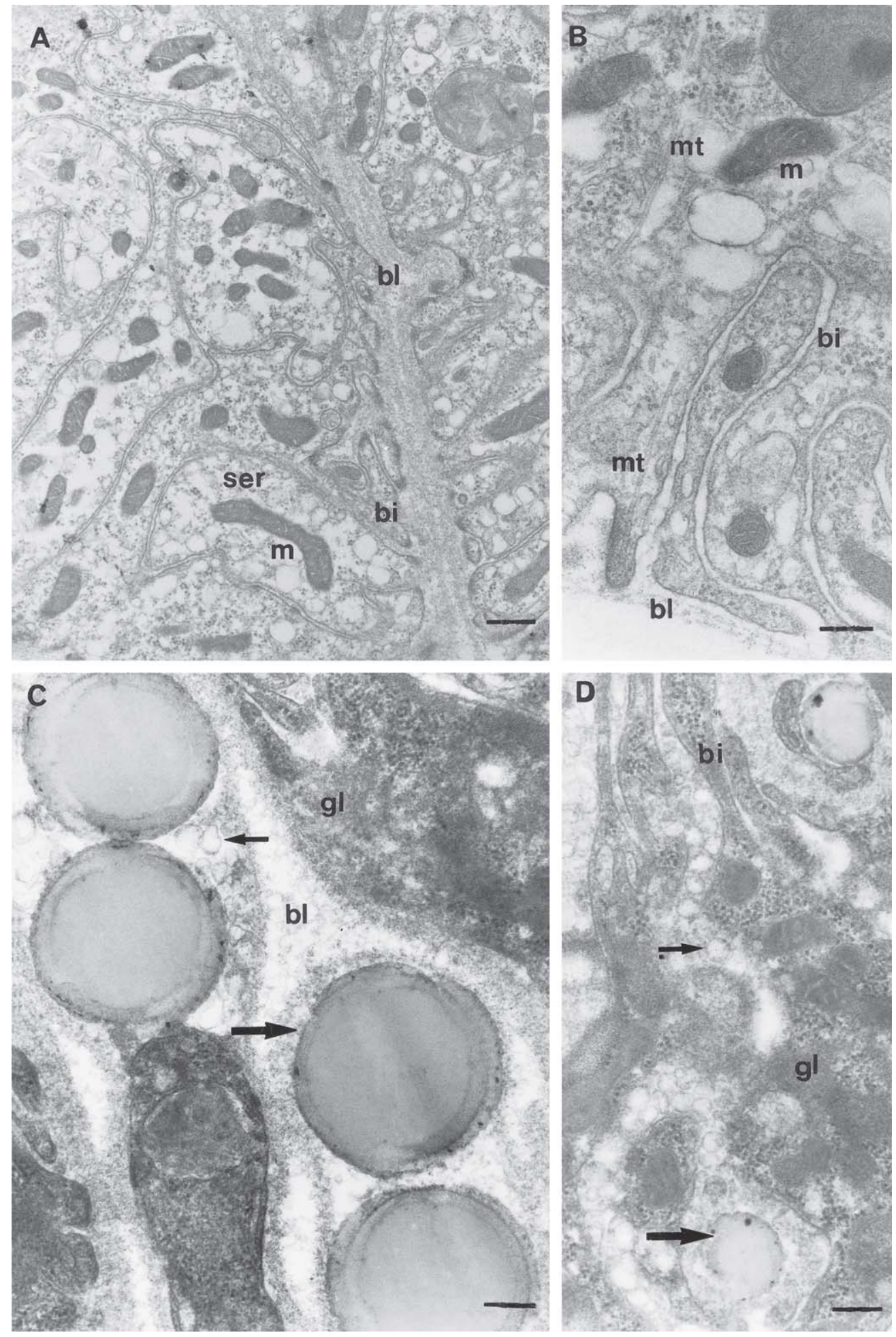

Fig. 3. TEM of virgin queens' Dufour gland. A) Detail of a fold of the glandular epithelium, where numerous basal plasmic membrane invaginations (bi) are observed. Notice that the epithelial fold is filled by an electron-transparent basal lamina (bl); m, mitochondria; ser, smooth endoplasmic reticule. Bar $=0.6 \mu \mathrm{m}$. B) Detail of loop-like basal plasmic membrane invagination (bi). Notice that the invagination attaches on the basal lamina (bl) through focal contact that from the electrondense portion of the invagination a microtubule (mt) is linked and sustains it; $\mathrm{m}$, mitochondria Bar $=0.2 \mu \mathrm{m}$. C) Basal portion of the gland, showing lipid granules (large arrow) associated with the basal lamina (bl). Electron-transparent small vesicles (small arrow) are also observed out of the gland (gl) cell associated with the basal lamina (bl). Bar $=0.30$ ìm. D) Detail of granules with ground electrondensity (larger arrow), smaller than those seen in C, among the plasmic membrane invaginations (bi) and electronlucid small vesicles (smaller arrow). Bar $=0.30 \mu \mathrm{m}$. 

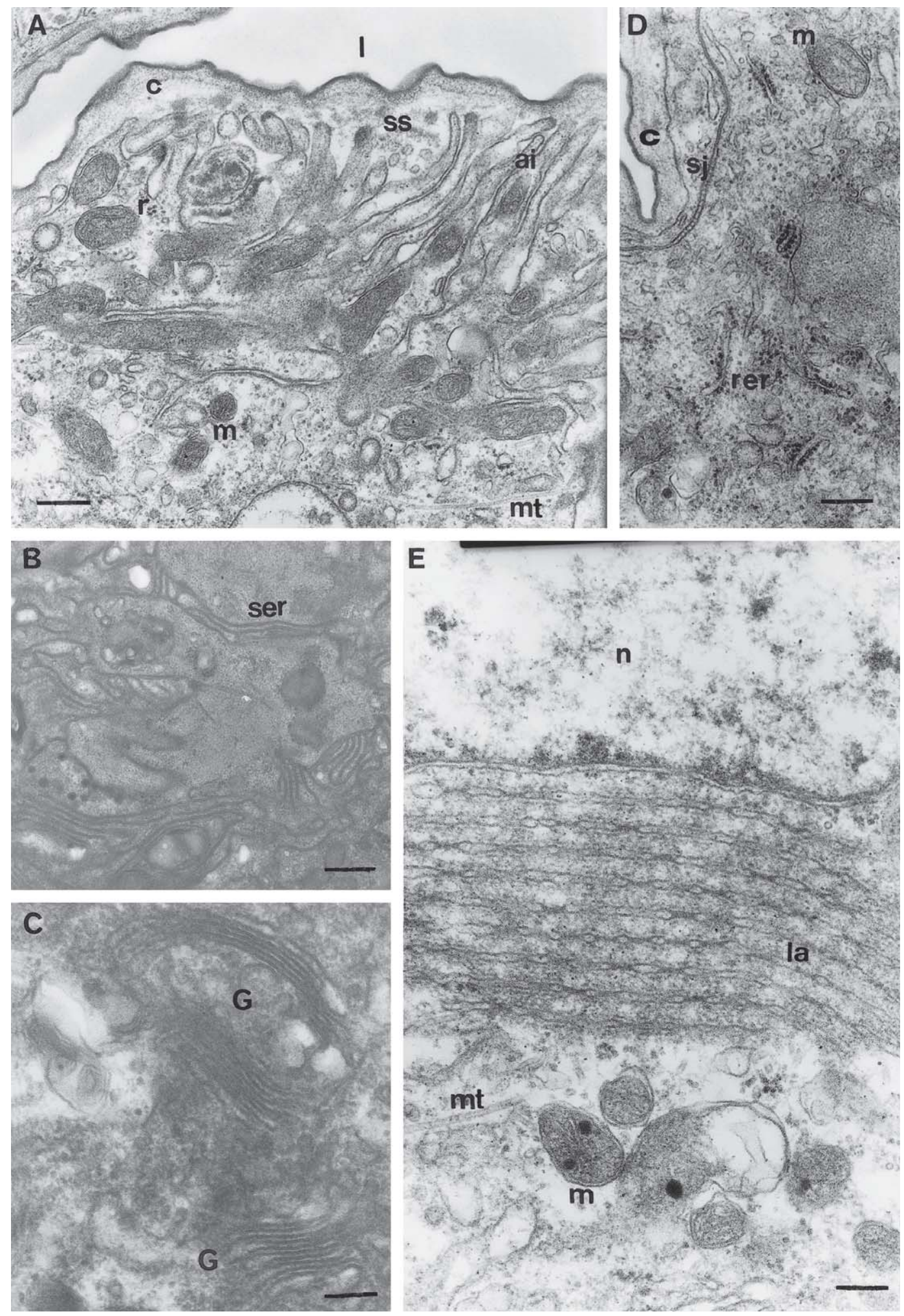

Fig. 4. TEM of physogastric queens' Dufour gland. A) Apical portion of a glandular cell, where numerous apical plasmic membrane invaginations are observed (ai); c, cuticle; m, mitochondria; $\mathrm{mt}$, microtubule; l, lumen; r, polyribosomes; ss, subcuticular space. Bar $=0.2 \mu \mathrm{m}$. B) Detail of the cytoplasm of a glandular cell, where a net of smooth endoplasmic reticule (ser) is observed. Bar $=0.2 \mu \mathrm{m}$. C) Detail of a cytoplasm portion with some Golgi (G) complexes. Bar $=0.2 \mu \mathrm{m}$. D) Portion of the glandular epithelium where rough endoplasmic reticule (rer) is observed; c, cuticle; sp, septated junction; $\mathrm{m}$, mitochondria. Bar $=0.1 \mu \mathrm{m}$. E) Nucleus (n) area, detailing annulated lamellae (la) associated to the nuclear envelope; $\mathrm{m}$, mitochondria; mt, microtubules. Bar $=0.01 \mu \mathrm{m}$. 

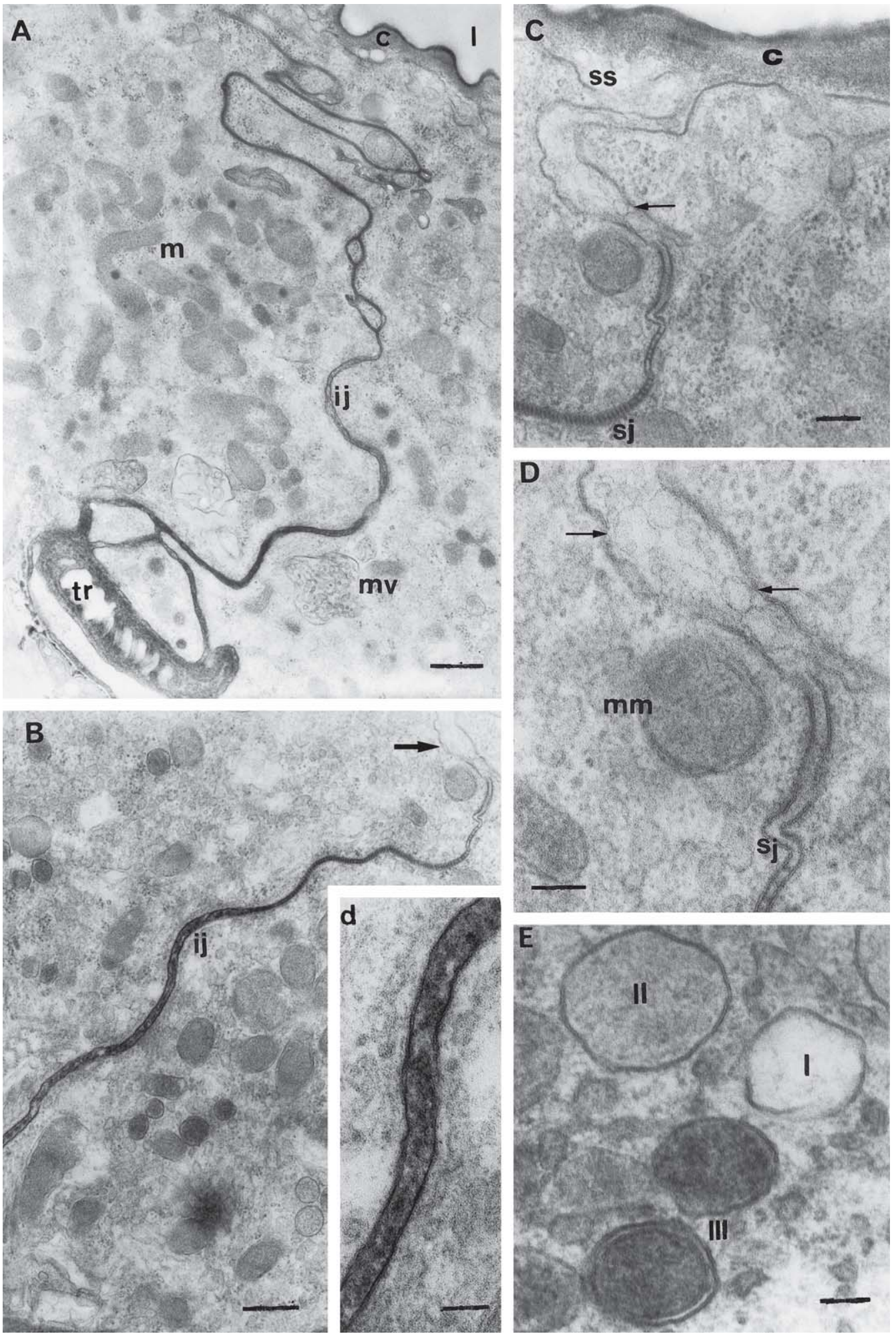

Fig. 5. TEM of physogastric queens' Dufour gland. A) General aspect of the area where two cells are connected for an intercellular junction (ij); $\mathrm{c}$, cuticle; $\mathrm{mv}=$ multivesicular body; $\mathrm{m}$, mitochondria; 1, lumen. Bar $=0.6 \mu \mathrm{m}$. B) Intercellular junction (ij) filled with electrondense material. Bar $=0.5 \mu \mathrm{m}$. In the right side, detail (d) of the intercellular junction seen in B. Bar $=0.1 \mu \mathrm{m}$. C) Apical portion of a glandular cell where it is noticed material in the subcuticular space (ss) that seems to come from the intercellular space (arrow). Bar $=0.2 \mu$ m. D) Detail of the figure C) where electronlucid vesicles (arrows) are noticed in subcuticular space; $\mathrm{sj}=$ septated junction; $\mathrm{mm}=$ modified mitochondria. Bar $=0.1 \mu \mathrm{m}$. E) Detail of modified mitochondria with one or more membrane units, presenting variable electrondensity; I, electron-transparent; II, medium electrondensity; III, electrondense. Bar $=0.1 \mu \mathrm{m}$. 

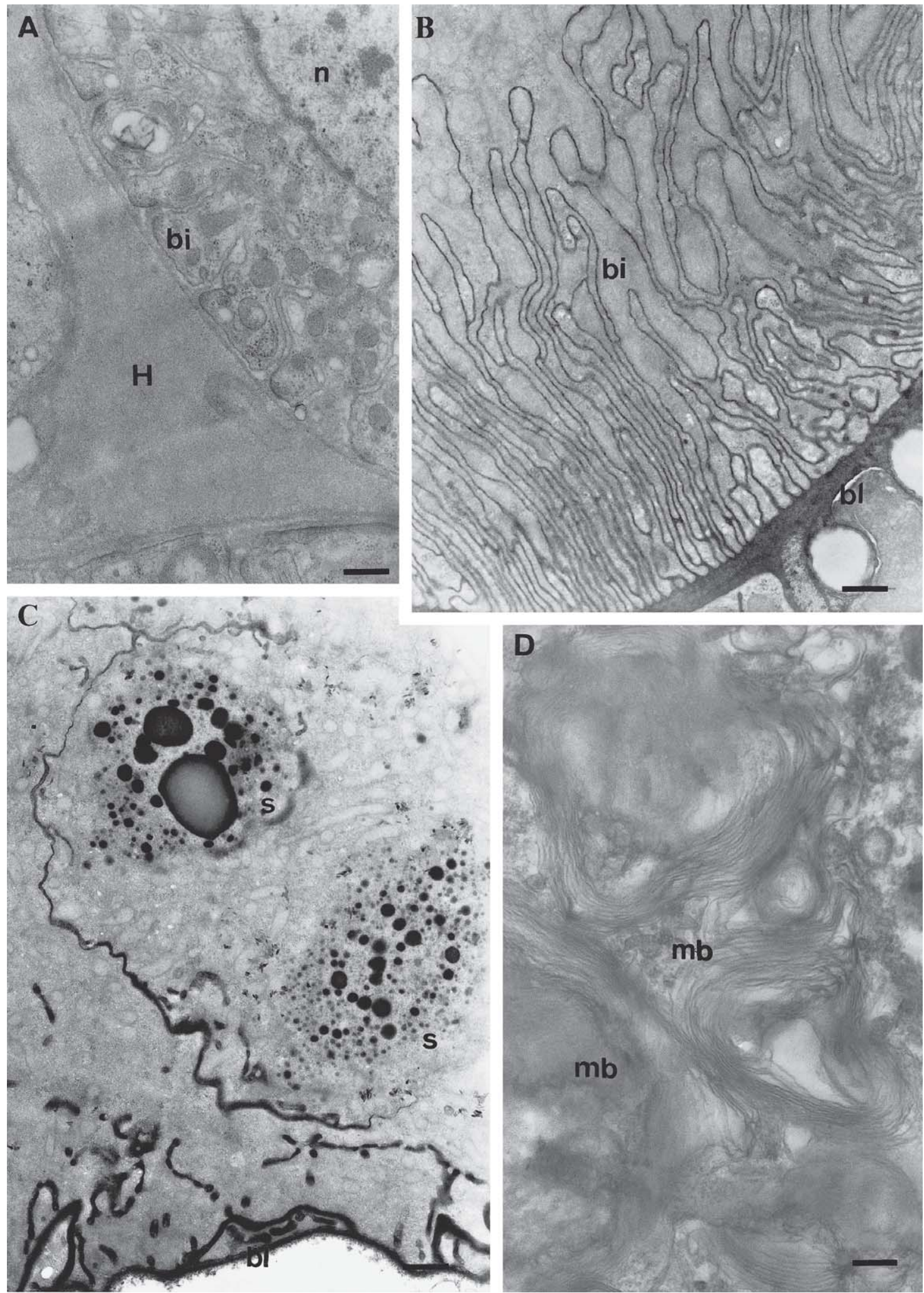

Fig. 6. TEM of physogastric queens' Dufour gland. A) Detail of a gland basal portion, showing material accumulation with ground electrondensity, probably hemolymph $(\mathrm{H})$, in the intercellular space; bi, basal plasmic membrane invagination; n, nucleus. Bar $=0.5 \mu \mathrm{m}$. B) Detail of a gland basal portion with numerous and deep basal plasmic invaginations (bi); bl, basal lamina. Bar $=0.9 \mu \mathrm{m}$. C) A gland basal portion with electrondense basal lamina (bl) and electrondense secretion granules $(\mathrm{s})$. Bar $=0.9 \mu \mathrm{m}$. D) Detail of the cytoplasm of a glandular cell basal portion, containing many myelinic bodies (md). Bar $=0.3 \mu \mathrm{m}$. 
because seemed to appear after a great gland activity and consequent re-absorption and rearrangement of the cell structure (AbDalla \& CRUZ-Landim 2001b).

Dufour gland morphometry in virgin and physogastric queens. The gland epithelium is lower in virgin $(13.5 \pm 0.3 \mathrm{~mm})$ than in physogastric $(21.4 \pm 0.3 \mathrm{~mm})$ queens (Tukey Test $\mathrm{P}>$ 0.05 ). The taller gland epithelium in the physogastric queens may be due to larger accumulation of intracellular secretion in the cells, which might increase its length. This may also indirectly indicate more intense cellular activity in physogastric queens. In anyway, the taller epithelium of the physogastric queen is a signal of high activity, confirmed by the ultrastructural data.

\section{CONCLUSIONS}

The present study adds new data to the interpretation of the Dufour gland as closely related to the reproductive apparatus in eusocial bees, but its exact function in reproduction is still unknown. Once the queen represents the reproductive caste, it seems natural that this gland may be more developed in the queens than in the workers. The absence of the gland in meliponine workers with developed ovary may be linked to the kind of function it plays in reproduction. If the gland function was directly linked to the egg laying, as apparently occurs in A. mellifera, in which laying workers have more active glands, it would be expected that the gland might be present in meliponine workers that lay eggs. However, if its function, as it seems to be the case, is to produce substance that identify the queen and/or the queen reproductive status, as the workers in stingless bees never assume the queen position (BEGO 1989), the gland is "dispensable" in this caste.

In the eusocial species, the reproduction is exercised often only by the queen, generating in some species the existence of a drastic morpho-functional and genetical differentiation between the female castes, which is enough to produce a condition of workers completely sterilized. In this case, it may be understandable that the Dufour gland, along the evolution, has become a relict or missing organ (ABDALla 2002), as it seems to be its status in the meliponine workers, where it is still present.

The fact that the Dufour gland is more developed in solitary bees than in eusocial ones and, among the social bees, more developed in the workers whose society is more rudimentary, e.g, in those with less complete reproductive division (LELLO 1968; AbDalla 2002), is another clue to the reproductive function of the gland. This condition shows that even the gland being related to the reproduction, its function may be variable within the reproductive process. The basal function of this gland in insects is protecting the eggs, producing hydrophobic lining or cement substances, as occur in many solitary bees or, as in other aculeate hymenopterans, to glue them to the substratum (GILLOT 1996). Therefore, in solitary bees, the gland is related to the nidification by direct involvement in nest construction or it is used for nest localization by the returning female. This occurrence is a good example of the function changes that may be acquired for the same organ in reason of selective pressures.

The Dufour gland cells do not fit completely well in the class I of NOIROT \& QUENNEDEY (1991), since the authors did not take in consideration the possibility of class I cells to be capable to absorb exogenous substances, not producing all their secretion compounds.

Finally, it may be said that the present results suggest clearly the involvement of the Dufour gland in the reproduction of M. bicolor, once it is more developed in physogastric than in virgin queens. One of the possibilities is the participation of the Dufour gland secretion in the complex interactions between the queens and workers, and among the physogastric queens of the same nest, during the oviposition and provisioning process - POP (ZuCCHI et al. 1994). As shown by bioassays with gland extracts (unpublished data), physogastric queens may use the gland secretion to recruit workers to start the POP.

Acknowledgments. The authors thank Dr. Lúcio Antônio de Oliveira Campos (Universidade Federal de Viçosa, Viçosa, MG, Brazil) and Luciane Cristina Lisboa (UNESP, Rio Claro, SP, Brazil) for supplying bees for this research. Special thank to Dr. Hayo Velthuis and Dr. Vera Lúcia Imperatriz Fonseca (USP, São Paulo, SP, Brazil) for the available informations of $M$. bicolor behavior. To FAPESP for financial support (grant 98/15070-2).

\section{REFERENCES}

AbDalla, F. C. 2002. Glândula de Dufour, p. 127-149. In: C. DA CruZLANDim \& F. C. AbDalla (eds.). Glândulas Exócrinas das Abelhas. Ribeirão Preto, Editora FUNPEC-RP, 181 p.

Abdalla, F. C. \& C. DA CruZ-Landim. 2001a. Behavioral responses evoked in honey bee workers by Dufour gland extracts (Hymenoptera:Apidae). Sociobiology 37: 673-678.

Abdalla, F. C. \& C. DA Cruz-landim. 2001b. Changes in the morphology of the Dufour gland of Apis mellifera L. (Hymenoptera, Apidae) during the life stages of the female castes. Revista Brasileira de Entomologia 45(2): 123-129.

Abdalla, F. C. \& C. Da Cruz-landim. 2001c. Dufour gland in the Hymenoptera (Apidae, Formicidae, Vespidae): a review. Revista Brasileira de Biologia 61: 95-106.

Abdalla, F. C. \& C. Da Cruz-landim. 2001d. Size differences in the Dufour gland of Apis mellifera (Hymenoptera, Apidae) between and within the female castes. Revista Brasileira de Zoologia 18(Supl. 1): 119-123.

Abdalla, F. C.; H. W. W. Velthuis; C. da Cruz-Landim \& M. J. Duchateau. 1999a. Changes in the morphology and ultrastructure of the Dufour's gland during the life cycle of the bumble bee queen, Bombus terrestris L. (Hymenoptera: Bombini). Netherlands Journal of Zoology 49: 251-261.

Abdalla, F. C.; H. H. W. Velthuis; M. J. Duchateau \& C. Da Cruz-Landim. 1999b. Secretory cycle of the Dufour's gland in workers of bumble bee Bombus terrestris (Hymenoptera: Bombini). Netherlands Journal of Zoology 49: 139-156.

Barrows, E. M.; G. B. Chapman; J. E. Zenel \& A. S. Blake. 1986. Ultrastructure of Dufour's glands in active and inactive horn-faced bees, Osmia cornifrons (Hymenoptera: Megachilidae). Journal 
of the Kansas Entomological Society 59: 480-493.

BEGO, L. R. 1989. Behavioral interactions among queens of the polygynic stingless bee Melipona bicolor bicolor Lepeletier (Hymenoptera, Apidae). Brazilian Journal of Medical and Biological Research 22: 587-596.

Billen, J. P. J. 1987. New structural aspects of the Dufour's gland and venom gland in social insects. Naturwissenschaften 74: 340 341.

Caetano, F. H. 2002. Ultra-estrutura e Enzimologia da Glândula Pósfaríngea de Dinoponera australis como Base para a Proposta de uma Nova Função (Hymenoptera, Formicidae), p. 39-43. In: M. E. Bauer \& E. A. Jeckel-Neto (eds.). Avanços em Biologia Celular. Porto Alegre, EDIPUCRS, $231 \mathrm{p}$.

Cruz-López, L.; E. F. L. R. A. Patrício \& E. D. Morgan. 2000. Secretion of stingless bees: the Dufour gland of Nannotrigona testaceicornis. Journal of Chemical Ecology 27: 69-80.

Fawcett, D. W. 1981. The Cell. Philadelphia, W.B. Saunders Company, $862 \mathrm{p}$.

Gillot, C. 1996. Arthropoda-Insecta, p. 319-471. In: Reproductive Biology of Invertebrates, VII (Acessory Sex Glands). England, A Willey-Interscience Publication, 519 p.

Hefetz, A. 1987. The role of Dufour's gland secretion in bees. Physiological Entomology 12: 243-253.

Katzav-Gozansky, T.; V. Soroker; A. Hefetz; M. Cojocaru; D. H. Erdmann \& W. Francke. 1997. Plasticity of caste-specific Dufour's gland secretion in the honey bee (Apis mellifera L.).
Naturwissenschaften 84: 238-241.

Katzav-Gozansky, T.; V. Soroker \& A. Hefetz. 2000. Plasticity in casterelated exocrine secretion biosynthesis in the honey bee (Apis mellifera). Journal of Insect Physiology 46: 993-998.

Kerr, W. E. 1949. Algumas comparações entre a abelha européia (Apis mellifera L.) e as abelhas nativas brasileiras (Meliponini). O Solo (outubro): 39-47.

Kerr, W. E. \& E. DE Lello. 1962. Sting glands in stingless bees - a vestigial character. Journal of the New York Entomological Society 70: 190-214.

LANE, N. J. 1981. Tight junctions in arthropod tissues. International Review of Cytology 73: 243-318.

Lello, E. 1968. Glândulas anexas ao aparelho de ferrão das abelhas (Hymenoptera: Apoidea). Tese de doutorado. Rio Claro: UNESP, 129 p.

Patrício, E. F. L. R. A. 1995. Glândulas de Dufour em abelhas sem ferrão. Tese de doutorado. Rio Claro, IBRC, UNESP, 166 p.

Noirot, C. \& A. Quennedey. 1991. Glands, gland cells, glandular units: some comments on terminology and classification. Annales de la Societé Entomologique de France (NS) 27: 123-128.

Zucchi, R.; E. V. Silva-Matos; F. H. Nogueira-Ferreira \& G. G. Azevedo. 1994. On the cell provisioning and oviposition process (POP) of the stingless bees- nomenclature reappraisal and evolutionary considerations (Hymenoptera, Apidae, Meliponinae). Sociobiology 34: 65-85. 